\title{
Anthropological Analysis in the Perspective of Ontology, Epistemology and Axiology
}

\author{
Corry $^{1}$, Ulung Napitu ${ }^{2}$, Wilson Simanjuntak ${ }^{3}$, Bakhrul Khair Amal ${ }^{4}$ \\ ${ }^{1,2}$ Postgraduate Program in Social Science Education, Postgraduate School, Simalungun University, Indonesia \\ ${ }^{3}$ Institute of Christian Religion, Tarutung, Indonesia \\ ${ }^{4}$ Universitas Negeri Medan, Indonesia \\ purbacorry470@gmail.com
}

\begin{abstract}
This library research aims to examine the existence of scientists as an independent science, which has a special method and at the same time the usefulness of anthropology in people's lives. The writing approach method used is a qualitative approach with a bibliographic method. This means that in writing this article the writer collects, selects, analyzes and presents various writings sourced from various literature books and other written sources. Syntheses from various sources are presented and assembled to obtain conclusions. The results of the literature review show that anthropology as an independent science fulfills the requirements for a philosophy of science that must contain elements of ontology, epistemology and axiology. These three elements are found in anthropology because anthropology has certain methods and benefits for many people's lives, which in the subsequent development of anthropology is not only a pure science but also an applied science.
\end{abstract}

\section{Keywords}

analysis; anthropology; ontology; epistemology; axiology

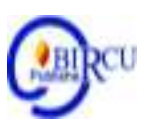

\section{Introduction}

Philosophy of science is part of epistemology (philosophy of knowledge) which specifically studies the nature of science with the characteristics of thinking that are comprehensive, fundamental and speculative (Garna, 2015). Science is different from knowledge but there is no very principal difference between natural science and social science. Science with the basis of ontology, epistemology and axiology means that all sciences have these three foundations, what differs is the material and its embodiment and the extent to which the foundations of the three aspects are developed and implemented (Suria Soemantri, 2010).

In the development of anthropology, the three foundations are absolutely analyzed in depth. Anthropology as a science is about humans. The science of anthropology is the study of human beings, trying to make generalizations about humans and their behavior and learn a complete understanding of human diversity (Havilan, 1988). Anthropology as a science discusses humans by examining the culture that gives them the ability to; (1) living together with the community, (2) being able to store knowledge obtained from the process of life; (3) have knowledge for the provision of life; (4) able to develop knowledge which is the secret of his power: (5) knowing what is right and wrong, good and bad, beautiful and ugly through norms and aesthetic values, (6) constantly forced in the process of social and environmental culture physical, (7) humans are the only ones who develop knowledge seriously in overcoming the need for survival, and (8) humans are able to develop culture and give meaning to their lives and humanize themselves in their lives (Garna, 2015; James, 2015). 
In the development of anthropology as a science that studies humans, culture, diversity and physical characteristics and their distribution in the world, it is inseparable from the three natures of the philosophy of science, namely: (a) Ontology; learn about the nature of what is studied by the science of anthropology, (b) epistemology; methods and procedures used to acquire and develop the science of anthropology and, (c) axiology; the value of the usefulness / usefulness of anthropology in human life (Soemantri, 2010). A similar view is expressed by (Garna, 2015) who argues that the basis of ontology is to talk about what objects are studied by science and produce knowledge, the epistemological basis is to discuss how / methods which allows the development of science as well as the basis of axiology is to discuss what science is used in relation to morals and ethics. Based on the point view above, it can be understood that every science including anthropology in its development must be based on the three aspects which cannot be separated from one to another.

For the development of anthropology, both theoretical anthropology and applied (implementative) anthropology, it is necessary to carry out field studies which require a relatively long time. Practical methods of anthropology are pursued through scientific research procedures starting from the formulation of problems, hypotheses, formulation of theoretical frameworks, discussion of research results and formulation of conclusions. Nowadays, the development of anthropology does not only use qualitative methods, but often combines qualitative and quantitative methods (Garna, 2015).

Anthropology as a science in its work in studying humans is related to other sciences, because in its implementation it is impossible for a science to solve socio-cultural phenomena (problems) in human life without relating to other sciences. For this reason, anthropology as a branch of the social sciences in analyzing various phenomena that occur in society should be related to other sciences such as: political science, economics. sociology, history, psychology, geography. law, biology and others (Harsoyo, 1988). Through this inter- and multidisciplinary relationship, it is hoped that anthropology, apart from being an independent science, is also able to solve various complex socio-cultural phenomena by using other scientific approaches so that the benefits and uses of anthropology are more efficient in the midst of human life (Garna, 2015).

\section{Research Methods}

In writing this scientific article, the writer took a method by carrying out library research (literature studies). Literature study (library) is a study that uses collection materials in the form of books, journals and other sources that are considered relevant without conducting field research (Danim, 2002; Zed, 2008). To answer the questions in this study, the authors use various documents that are considered relevant to solving problems, through collecting, evaluating, synthesizing, analyzing, and carrying out internal and external criticism of the content from various sources (Kerlinger, 1986; Bugin, 2008; Creswell, 2015).

Referring to this opinion, this research is conducted by selecting and sorting books, journals and other literature related to the philosophy of science and anthropology that stand alone as science by fulfilling the elements of ontology, epistemology, and axiology. To ensure the validity and legitimacy of various sources, the authors carry out evaluation, content analysis, and synthesis of related sources. 
This means that written sources related to the existence of anthropology as an independent science are carried out by evaluating, comparing, analyzing, and synthesizing various sources so that they can be formulated to reach a conclusion.

\section{Results and Discussion}

\subsection{Ontology (The Essence of Anthropology)}

Anthropology as a science is the study of arthropods or human beings, is an integration of several sciences, each of which studies a complex of special problems regarding human beings. The integration process is a long development process that began at the beginning of the 19th century and continues until now. The integration reached a concrete form after more than sixty anthropologists from various European-American countries including the Soviet Union met to hold the International Symposium on Anthropology in 1951. This symposium aims to conduct a comprehensive review of the scientific activities that have been achieved by anthropologists, with the publication of the book -books like Anthropology Today reduced by AL Kroeber (1953), An Appraisal of Anthropology Today reduced by S. Tax et. al. (1954), Yearbook of Anthropology reduced by W.L. Thomas Jr. (1955), and Current Anthropology reduced by W.L. Thomas Jr. (1956) (Koentjaraningrat, 2007).

The integration that was achieved after 1951, has now been realized by many experts in various countries where anthropology lives and this can be seen from anthropology textbooks. However, almost every country that studies anthropology has adapted it to its own ideology and needs. This is because in addition to academic science, anthropology also has many practical aspects.

Harsoyo (1988) states that anthropology is a science that studies human beings as social beings. The attention of anthropology is focused on bodily specificities and modes of production, traditions and values that make one life different from another. Judging from anthropology, humans can be analyzed from two aspects, namely humans as biological beings and humans as socio-cultural creatures. In this formulation, anthropology does not see biological humans and sociocultural humans separately, but holistically as a unified cultural biosocial phenomenon.

Thus the science of anthropology in discussing humans is holistic in various countries and the development of anthropology as a different science, not only about the applied aspects of anthropology, but also in terms of methodology and theory (Koentjaraningrat, 2007).

In order to reach a real understanding of the scope and basis of anthropology, which has not yet achieved stabilization and a uniform general form in all scientific centers of the world, it is actually not enough just to delve into this general form of integration of the human sciences, achieved in the International Symposium on Anthropology. The best way to reach understanding is to study what the basic sciences are, and what is the outline of the developmental process that integrates these basic sciences. Then learn how it is applied in different countries. Understanding the boundaries and principles of similar anthropology will only be useful for us to know what anthropology really means for Indonesia today, namely Indonesia in its current development period which is experiencing various problems and is related to human society. To study and analyze in more depth the process of anthropology as a science can be known through the following phases: 


\section{a. First Phase (Before 1800)}

The arrival of Western Europeans to the continent of Africa, Asia, and America from the end of the 15th century to the beginning of the 16th century had an influence on various ethnic groups on the three continents. At the same time, the writings of travelers, sailors, preachers of Christianity, translators of the Bible, and colonial government employees began to be collected in the form of travel stories, reports and so on.

In Western Europe there are three kinds of opposing attitudes towards the peoples of Africa, Asia, Oscania, and the Indians in America, namely:

a) There are those who think that these nations are not real humans, but they are savages, descendants of demons and so on. Thus, terms such as savages, primitives arise to refer to these nations;

b) There are those who think that the society of these nations is an example of a society that is still pure, not yet familiar with the evil and evil that existed in the society of the nations of West Europe at that time.

c) Some were interested in strange customs, and began to collect cultural objects from ethnic groups in Africa, Asia, Oceania and indigenous America (Thomson, 1841; Koentjaraningrat, 2009).

Some of these collections of personal records were compiled into one, so that they could be seen by the public, thus the first museums about the cultures of nations outside Europe emerged.

\section{b. Second Phase (Correct Mid-19th Century)}

Real integration emerged in the mid-19th century. Ethnographic essays are structured based on the evolutionary way of thinking of society. In short, the way of thinking can be formulated as follows that human society and culture have evolved very slowly over thousands of years starting from the lowest levels, through several intermediate levels, to the highest levels.

In this second phase of development, anthropology is an academic science, aiming to study primitive societies and cultures with a view to gaining an understanding of ancient levels in the history of evolution and the history of the spread of human culture (Harsoyo, 1988, Koentjaraningrat, 2009).

\section{c. Third Phase (Beginning of the 20th Century)}

At the beginning of the 20th century, some of the colonizing countries in Europe managed to achieve stability in their power in colonized areas outside Europe. For the purposes of the colonial government, which at that time began to deal directly with colonized nations outside Europe, the science of anthropology as a science actually studied the nations in areas outside Europe, became very important.

Anthropology, with the characteristics described above, developed in England as the main colonizing country, as well as almost all other colonial countries. Even the United States, which is not a colonial country, has experienced various problems related to the Indian tribes of the indigenous population of the Americas, influenced by the new anthropological science. In this third phase, anthropology becomes a practical science, and its objectives can be formulated as follows: studying the society and culture of ethnic groups outside Europe for the benefit of the colonial government and in order to gain an understanding of today's complex society (Koentjaraningrat, 2009). 


\section{d. Fourth Phase (After Approx. 1930)}

In this phase the science of anthropology experienced the most extensive development, the addition of material knowledge that was far more thorough, and the sharpness of its scientific methods. In addition, there are two changes in the world, namely: a) The emergence of antipathy to colonialism after World War II, b) The rapid disappearance of primitive nations (native and isolated nations from the influence of European-American culture), and after World War II almost no more on this earth (Koentjaraningrat, 2009). The goal, the science of anthropology, which is just in its fourth phase of its development, can be divided into two, namely academic goals and practical goals. The academic goal is to achieve an understanding of human beings in general by studying the diversity of their physical forms, society, and culture. The practical goal is to study humans in the diversity of ethnic communities in order to build ethnic communities (Koentjaraningrat, 2009).

Cultural anthropology is used in America, then in other countries as a term to refer to a part of anthropology in a broad sense that does not study humans from a physical point of view, now the term is officially used by the University of Indonesia as cultural anthropology, to replace the term G.J. Holds cultural science. Social anthropology is used in England to refer to anthropology in its third phase, as opposed to ethnology, which is used to refer to the anthropology of the earlier phases. In America, various conflicting methods are harmonized into one, namely, social anthropology and ethnology are two subsections of anthropology. In the United States universities, where anthropology develops with its wide scope and boundaries, it causes at least five research problems, namely; 1). Historical problems of the origin and development of humans (or their evolution) biologically, 2). Historical problem of the occurrence of various human beings, from the point of view of the characteristics of their bodies, 3). Historical problems of the origin, development, and spread of the various languages spoken by humans around the world, 4). problems of the development, spread, and occurrence of various human cultures around the world, 5). problems regarding the principles of human culture in the lives of people from all ethnic groups scattered throughout the earth (Koentjaraningrat, 2009).

This field of research aims to solve these five problems. Each of them is a part of anthropology that requires experts. In connection with the specialization of the five fields, anthropology also recognizes the sub-disciplines, namely:

1) Paleo-anthropology

2) Physical anthropology

Called physical anthropology in a broad sense

3) Ethno linguistics

4) Prehistory

5) Ethnology

Called cultural anthropology

Paleo-anthropology called physical anthropology in the broad sense of physical anthropology Ethno linguistics. Paleo-anthropology is a branch of science that examines the origin or occurrence of human evolution by using the remains of a body that has been petrified (human fossils) stored in the layers of the earth.

Physical anthropology in a special sense is part of the science of anthropology that tries to reach an understanding of the history of the occurrence of various human beings from the point of view of the characteristics of their bodies. The research material is body characteristics, as well as phenotypes such as skin color, hair color and shape, skull index, 
face shape, eye color, nose shape, height and body shape, as well as deep (genotype), such as blood type frequency and so on.

From the point of view of the field of investigation, physical anthropology is divided into smaller branches of science such as:

a. Primate paleontology, namely the study of descriptions of human varieties that no longer exist in the world today and of other creatures that are still closely related to humans.

b. Human evolution, namely the science that studies the process of development of the human type starting from non-human beings.

c. Anthropometry, namely the study of techniques for measuring the human body.

d. Somatology, which is the study of living human varieties and of sex differences and individual variations.

e. Racial anthropology, namely the study of the classification of humans into racial groups, the history of races and racial mixing.

f. Comparative studies of organic growth and constitutional anthropology that study the predisposition of human body types to certain diseases and specific behaviors such as criminal behavior (Kluckhon, 1949; Harsoyo, 1988).

Anthropology consists of: Biological anthropology and cultural anthropology. Cultural anthropology is divided into: Paleo Anthropology and Physical Anthropology. Cultural anthropology consists of 5 (five) sections: 1) Prehistory, 2) Ethno linguistics, 3) Ethnology, 4) Ethno psychology, 5) Specialized Anthropology and 6) Applied Anthropology. Ethnology is divided into 2 (two), Descriptive integration (Ethnology) and Generalizing approach (Social Anthropology). Anthropology specialization includes 7 (seven) sections, namely: Anthropology of economy, politics, culture, health, mental health, education and urban (Koentjaraningrat, 2009).

The process of developing anthropology as an independent science begins with the birth of various theories which in subsequent developments are known as paradigms. During the development of anthropology to date, there are 15 (fifteen) anthropological paradigms, namely: evolutionism paradigm, diffusions, historical particularize (Historical Anthropology), functionalism, variable analysis, cross-cultural, personality and culture (Culture and Personality), structuralism (Levi-Strauss), cultural interpretation, cultural materialism, historical materialism, ethno science, constructionist (phenomenology), actororiented, post-modernism (Ahimsa, 2011).

Anthropology has an object that is discussing humans, culture and diversity and in anthropology also found the main characteristics of science, namely: Anthropology is rational, has objective methods, empirical, compiled based on experience, general and accumulative (Harsoyo, 1998).

\subsection{Epistemology (Methods) Used in the Development of Anthropology}

Simply put, epistemology can be defined as a theory of knowledge. Epistemology discusses, among others, the origin of knowledge, sources of knowledge, criteria for knowledge, and the differences between them and science. According to its etymology, epistemology comes from the words episteme, "knowledge" and logos, science, so that literally "epistemology" is defined as "the science of knowledge" or "theory of knowledge". Epistemology is also defined as "the philosophical examination of human knowledge" (Encyclopedia Americana vol. 10, 1973), or "the philosophical study of human knowledge", (The World University Encyclopedia, vol. 4, 1965), namely "a branch of philosophy that studies sources, limits, methods and validity of knowledge". The study of epistemology is basically a study of more philosophical knowledge. Such a definition is still unclear. 
More specifically H.P. Rickman (1967) says that epistemology basically talks about: (a) what principles and prepositions are involved when people know something, (b) whether and how these principles and prepositions change when the subject of the study also changes and what implications for the methods used, (c) general concepts that refer to the phenomena studied or to the phenomena that exist in human life, and (d) how to relate important general concepts to each other in a way systematic.

Because epistemology is philosophical, within the framework of the paradigm above, this section includes implicit elements, which consist of basic assumptions, ethos (values) and models. The basic assumptions are the elements that Rickman calls principles and presuppositions, which vary based on the problem studied. In anthropology, this epistemology is then equated with the philosophy of anthropology. The philosophy of socio-cultural science has developed rapidly since Comte put forward his ideas on the philosophy of positivism as the basis of science. Therefore, the epistemological map in anthropology is not the same as the paradigm map. Epistemology here is part of a paradigm, but a relatively more important part than the other elements.

The basic assumptions in the anthropological paradigm need to be known further from its constituent elements. Based on the results of a study of various basic assumptions in various anthropological paradigms, it was found that at least six basic assumptions became the philosophical basis of these paradigms. These assumptions relate to: (a) the knowledge base, (b) humans, (c) the phenomenon being studied or its material object: (d) science, (e) social/cultural science, and (f) disciplines or branches of science studied, can be described by a scheme such as the following:

Table 1.The Epistemological Basis of Anthropological Paradigms

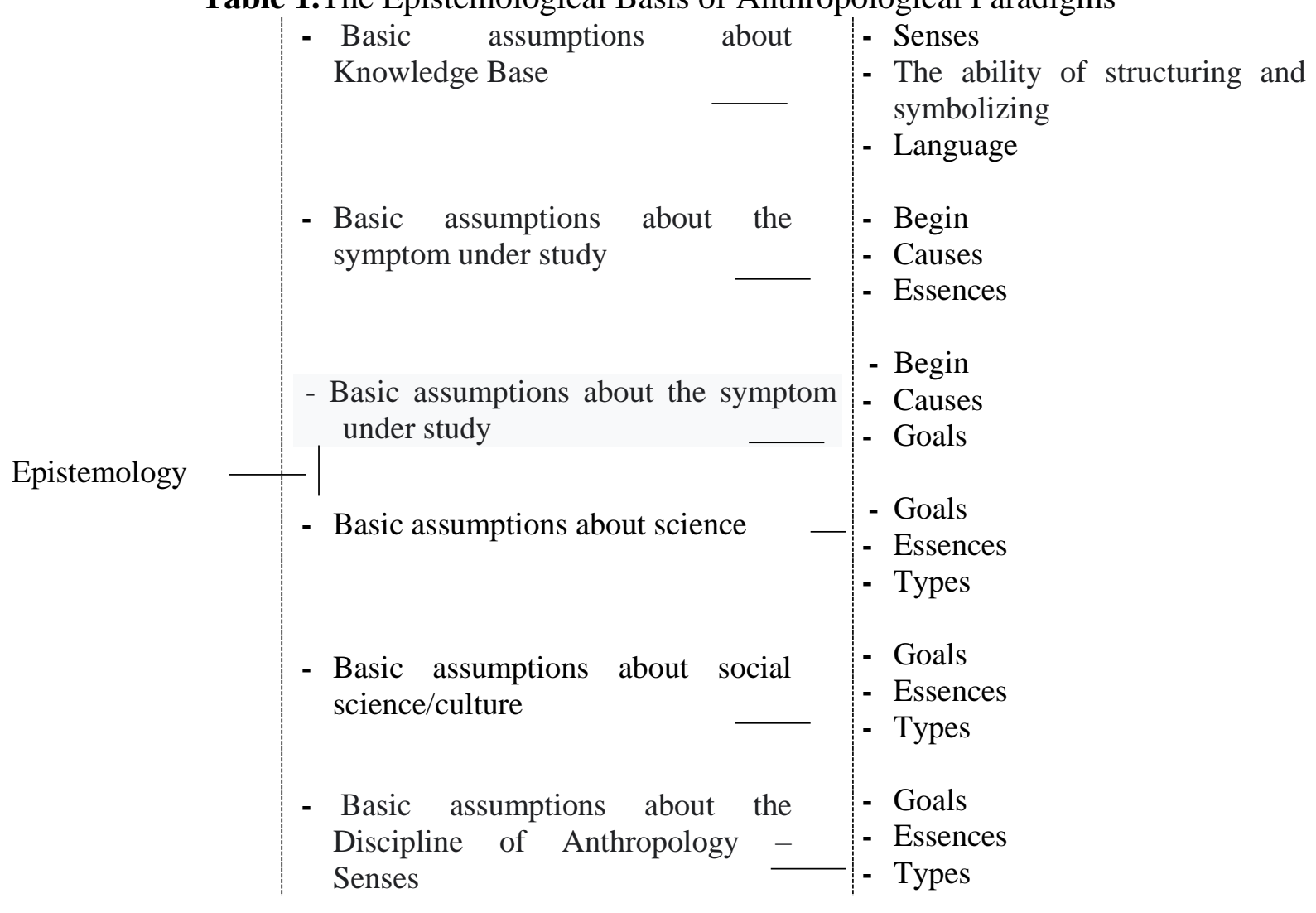


By using these six basic assumptions, it is tried to find the types of epistemology found in anthropology. Broadly speaking, there are seven types of epistemology in anthropology, namely: (1) Positivism, (2) Historicism, (3) Phenomenology, (4) Hermeneutics, (5) Structuralism (Semiotics): (6) Historical Materialism: (7) PostModernism. This epistemology then becomes the philosophical basis for anthropological paradigms that have been identified previously (Mursal, 1999, Christ, 2008, Ahimsa, 2011).

The requirement of science is that it has a method (way) to work and develop science itself. Likewise with anthropology, its epistemology is related to the various methods used in scientific field research. Anthropological scientific method is a coherent thinking procedure used in research to obtain scientific conclusions based on certain scientific postulates and presuppositions, with the principle; statement of research problems, problem solving and verification of problem solving (Harsoyo, 1988).

The scientific method of science is all the means used in the science, to achieve a unity of knowledge. Without the scientific method, a science is not a science but a collection of knowledge, about various natural phenomena or society without any awareness of the relationship between the phenomena that occur. The unity of knowledge can be achieved by the concerned science scholars through three levels, namely: 1) data collection, 2) determination of general characteristics and systems, and 3) verification (Koentjaraningrat, 2009). For anthropology, this level is the collection of facts about the events and phenomena of society and culture for scientific processing. In reality, the factgathering activity here consists of various methods of observing, recording, processing, and describing the facts that occur in a living society (Garna, 2011).

Field research anthropology is the most important way to gather facts and research in libraries. Meanwhile, research methods in the laboratory are the main fact-gathering methods in the natural sciences and technology, which are almost meaningless in anthropological research.

In field research, anthropological researchers unite in the society under study to obtain information about the symptoms of human life in that society. From the observations, most of the information material was obtained and the community members were the informants. Cultural anthropologists are particularly interested in human actions and behavior in small group relationships. Such groups do not exceed 3,000 individuals, who are selected for special and in-depth research on various aspects. This causes a cultural-anthropology researcher to use qualitative data collection methods. The methods in the form of interviews and results notes (Harsoyo, 1988).

Field notes that have been collected must be converted into writing that can be used and processed into theories about cultural principles, or to increase knowledge for researchers who will go directly to the field. Turning field notes into essays that other people can read requires a set of methods of its own. Real material recorded in the form of field notes must be processed into a descriptive essay. The first thing to do is to make an abstraction of the existing material in the form of statements.

All of the methods used, from the method of collecting data about a living community, to the method of processing data into an essay that can be read by others is a descriptive field of anthropology called ethnography. The term ethnography which means a description of ethnos or ethnicity, besides containing the meaning of all descriptive anthropological methods, is also material about community life and culture in an area and ethnographic books are books that contain descriptions of the life of a society and culture in an area (Spradley, 2003). 2006). The manual that is usually used by an ethnographic researcher is Notes and Queries on Anthropology (1951), a guidebook for anthropological 
methods, the most recent of which is the book compiled by R. Naroll and R. Cohen, entitled A Handbook of Methods in Cultural Anthropology (1970). ) (Koentjaraningrat, 2009).

Methods for verification or testing consist of ways of testing the formulation of rules or strengthening the understanding that has been achieved, carried out in the realities of nature or living society. Here the thought process runs deductively, namely from general formulations back to specific facts. Anthropology, which contains more knowledge based on "understanding" than knowledge based on rules, uses qualitative verification methods. By using qualitative methods, anthropology tries to strengthen its understanding by applying that understanding in reality, namely to some living communities, but in a specific and deep way (Harsoyo, 1988; Koentjaraningrat, 2009).

Methods in the scientific sense, are all ways to achieve unity of knowledge about the object of a branch of science. The cultural-anthropological method is a way to achieve a unified knowledge of the object of cultural-anthropological science. The unit of the method consists of;

a) Critical discrimination,

b) Determination of generality and system,

c) Empirical verification. (Pearson, 1950; Sumantri, 2009)

To achieve critical discrimination, or critical limitation of the information, consists of methods for collecting, recording, compiling and methods for describing the phenomena of society and culture. To go towards the determination of generality and system or the determination of general principles and systems is called the interpretive aspect of science (Koentjaraningrat, 1958).

This aspect gives rise to a method that seeks to find the same factors, connecting various symptoms of society and culture with the symptoms of society and culture. This method is in the form of assumptions or theories that provide information or interpretation of various social and cultural phenomena. With this interpretation, general principles appear in phenomena and systems in knowledge emerge. The way to go towards empirical verification consists of methods that want to further test the general principles of the system that have been obtained in the reality of human society and culture (Koentjaraningrat, 1958).

\subsection{Axiology Benefits (Usage) Anthropology}

Knowledge that is not practiced is like a shady tree that does not bear fruit in the end it is only used as firewood (Marzali, 2007). Starting from this expression, that all science in its development including anthropology must be guided by axiology, namely; every science must be useful and beneficial academically and practically for the benefit of mankind. Anthropology is useful for humans to answer challenges and as problem solving for various socio-cultural problems faced in development. From experience in other places, it turns out that applied anthropology is able to answer the needs of the community, participate in building and the need to build a better personal character (Sumantri, 2009).

The development of the field of anthropology has long been mandated by the father of Indonesian Anthropology, the late Koentjaraningrat. He specifically stated that "Indonesian anthropology that is suitable for today's needs is anthropology which can research and analyze sociocultural factors related to the development efforts of our country today" (Koentjaraningrat, 1969). This means that anthropology is able to contribute in solving basic problems, namely the problem of population pressure, lack of agricultural land, and mass poverty (Marzali, 2007). 
The socio-cultural problem in Indonesia after independence until now is population growth which is not accommodated by agricultural land. This phenomenon causes mass unemployment in the countryside. When these unemployed people urbanize to the city, and in the city they find the same problem, because the government has not been able to fully address this problem completely, many of them have slipped into the informal sector, crime, unemployment, and disguised unemployment. They bring these social problems to the nation nationally. Meanwhile, some other rural unemployed go inland or climb mountains and enter the forest illegally, others go to the sea and catch fish using bombs, all contributing to many environmental problems nationally (Garna, 1987; Marzali, 2007) .

Now, more serious social problems have surfaced. To overcome these sociocultural problems, anthropologists should have the thinking capital to participate in finding policy formulations for solving them. The father of American anthropology, Franz Boas, was convinced of this 70 years ago, why do we who live today still doubt it? Mandated by Boas, "I believe we have seen that a knowledge of anthropology may guide us in many of our policies" (Boas, 1962; Marzali, 2007).

In general, applied anthropology is a field within anthropology where knowledge, skills, and perspectives of anthropology are used to help find solutions to practical human problems and facilitate development. Applied anthropology as "the field of inquiry which is concerned with the relationships between anthropological knowledge and the uses of that knowledge in the world beyond anthropology" (Chambers, 1989). Strategically, in applied anthropological studies, it must show how theoretical concepts empirically applied to sociocultural reality, which in turn this empirical analysis will be useful for practical purposes and at the same time provide feedback for the development of anthropological theories and concepts. In applied anthropology, theory and practice are dialectically mutually reinforcing (Marzali, 2007).

The work pattern of applied anthropology is almost the same as that of other applied sciences. Applied anthropologists are not only required to diagnose sociocultural problems in a society and provide treatment recommendations, but also must develop instruments for diagnostic work, conduct investigations to find solutions to these sociocultural problems, and supervise treatment (Thompson, 1963).

Models in anthropology to optimize the use of anthropology include: The first capital, the tradition of the anthropological approach called systemic-holistic. In this approach, every policy is always seen by anthropologists in terms of the context of society as a whole, with policies made in other areas of life, with the natural and social environment, with values and beliefs that live in society, and so on.

The second modal, the emic approach, is to see everything from the local community's point of view, or in popular terms it is called the native's point of view. This approach comes from the ideology of cultural relativism, that there is no high-low measurement in culture, every society has a unique culture according to their values, beliefs, and living environment. The third capital, the "cross-cultural-comparative" approach. This approach is a typical method of anthropology in drawing generalizations or general conclusions. Anthropology has not traditionally used statistical methods. The advantage of this comparative approach is the encouragement to collect a broad and massive ethnographic treasure, including stories about the various ways that various social groups usually deal with the problems of life they face. The fourth modal is a symbolic approach or cultural interpretation. In the life of traditional Indonesian rural communities, people used to use symbolic language. Desire or intention is not expressed openly, especially if the intention carries the risk of being opposed by many people. The fifth modal is the ethnographic approach. Public policy making requires in-depth and 
intertwined information about target communities, especially when decision makers have little knowledge of these communities. The sixth capital is the habit of anthropological studies that focus on the life of local communities (Marzali, 2012).

There are four elements that distinguish applied anthropology (anthropology) from abstract anthropology, namely; The first category is applied anthropology which studies or deals with living cultures and social groups living in the present (Living cultures and contemporary peoples). While abstract anthropology tends to study past societies and cultures, including those that have run aground from real life today. The second category, applied anthropological studies, deals with the real needs and problems faced by social groups today, such as ethnic conflicts, unemployment, mental disorders of people affected by floods, migrant workers, drug abuse, HIV/AIDS, structural poverty, ethnic cleansing, and etc. Meanwhile abstract anthropology pays much attention to the problem of the diffusion of the oval ax in the prehistoric era of the Archipelago, the belief system of the Kubu people, the hunting-gathering life of the Tugutil people, which generally do not have much to do with the real needs and problems faced by today's societies.

Third, applied anthropologists will apply their findings, data, and analysis to fields outside of anthropology, particularly in the field of public interest. As a result, applied anthropologists often work interdisciplinary, working closely with experts from other disciplines. They research new problems in anthropology and collect data on the basis of their relevance to current issues. For abstract anthropologists, data analysis is intended to sharpen scientific debates among anthropologists. The thoughts of past anthropologists are very decisive in the selection of research methods, research problems, and objects of study (Marzali, 2007).

Abstract anthropologists usually work in anthropological education and research in universities and museums. Meanwhile, applied anthropologists generally work as professionals in non-academic institutions. Even if they work in the field of higher education, they are usually attached to the non-anthropology department (Eddy \& Partridge, 1987).

Broadly speaking, Podolefsky \& Brown (1994) divides the work of applied anthropology into four categories of fields. The first category is research work which contains both abstract anthropology and applied anthropology. From an abstract anthropological point of view, this study aims to develop and test cultural materialist and macro sociology theories into empirical facts that have emerged among indigenous tribes in Simbu Province, in the mountains of Papua New Guinea. From the perspective of applied anthropology, this study can provide deeper insight to decision makers on the issue of inter-tribal wars, which in turn can be used to formulate policies and programs to help stop inter-tribal wars in the region.

The second category is research conducted by anthropologists for a government agency, a company, or a particular group with specific objectives as requested by the client. A business anthropologist, for example, is asked by a particular company to find ways to increase the creativity and productivity of that company's staff.

In the third category, anthropologists work as consultants for government agencies or private companies that require deep sociocultural knowledge in solving problems faced by these clients. In this case, anthropologists act as cultural brokers, mediators, or advisors who mediate two conflicting parties.

The fourth category is the area of implementation of development programs. In certain fields, some anthropologists can develop in-depth knowledge, in such a way that they are able to manage a development project (Marzali, 2007). 
Anthropologists who have been involved in various development projects are problem solving. Anthropologists are able to work in all stages of development project work, starting from (1) researching, finding and determining community needs, (2) formulating policies and choosing alternative solutions to problems faced by the community, (3) planning and implementing projects in accordance with policies. and plans that have been established, and (4) assessing project work through evaluation research (Robert and Fiskel, 1991).

Now anthropologists after receiving applied education, can and are able to participate in every stage of development projects, especially those related to socio-cultural problems faced by the community and other social vulnerabilities as a result of development itself.

\section{Conclusion}

1. Anthropology in its development cannot be separated from aspects of ontology, epistemology and axiology as part of philosophy and knowledge.

2. Anthropology is viewed from the perspective of ontology that the essence of anthropology is the study of humans, culture, physical characteristics and ethnic diversity as objects of anthropology.

3. In developing the science of anthropology, it is pursued through the use of qualitative methods, in-depth understanding and participation in observations with scientific procedures starting with the formulation of the problem, formulation of hypotheses, framework of thought/review of literature, discussion of research to draw conclusions.

4. Anthropology is a part of social science which discusses humans, culture, ethnic and ethnic diversity in the world in carrying out their practical academic functions in collaboration with other sciences (multidisciplinary) without neglecting anthropology as an independent science.

5. Every science has its benefits and uses, because if science is not put into practice, it is likened to that knowledge is the same as a shady tree that does not bear fruit that is used only as firewood. Likewise, anthropology, besides being useful for the development of science itself in academic studies, also has practical uses for solving socio-cultural phenomena faced by human society which are so complex by not ignoring the moral and ethical principles of science which are not value free and value free.

\section{References}

Bakker, Anton. 2000. Antropologi Metafisik. Jakarta : Pustaka Filsafat.

Esten. Mursal. 1999. Kajian Transformasi Budaya. Bandung, Angkasa.

Garna K. Judistira. 1987. Metode Penelitian Kualitatif. Bandung : Primaco. 1987. Tradisi Transformasi Modernisasi dan Tantangan Masa Depan

di Nusantara. Bandung : Primaco. 2009. Dasar dan Arah Penelitian Ilmu Sosial. Bandung : Primaco. 2010. Filsafat Ilmu. Bandung : Primaco.

Harsoyo, 1988. Pengantar Antropologi. Bandung : Binacipta.

Jenks, Chris, 2008. Kebudayaan. Medan : Bina Mulia Perintis.

Keesing, M. Roger. 1999. Antropologi Budaya Suatu Perspektif Kontemporer. Jakarta : Erlangga.

Koentjaraningrat, 1958. Metode Antropologi dalam Penyelidikan Masyarakat dan Kebudayaan Indonesia. Jakarta: Permata. 
1987. Sejarah Teori Antropologi. Jilid 1, Jakarta: UI Press.

. 1990. Sejarah Teori Antropologi. Jilid 2. Jakarta : UI Press.

2009. Pengantar Ilmu Antropologi. Jakarta : Rineka Cipta.

Mazzali, Amri. 2007. Antropologi Pembangunan Indonesia. Jakarta : Kencana.

.2012. Antropologi dan Kebijakan Publik. Jakarta : Kencana.

Max Weber. 2013.Teori Dasar Analisis Kebudayaan. Yogyakarta : Ircisad.

Noerhadi, Herawaty T. 2013. Alur dalam Budaya. Jakarta : Gramedia.

Putra, Ahimsa. 2011. Paradigma, Epistemologi dan Etnografi dalam Antropologi. Jogjakarta : Gadjah Mada Press.

Saifuddin, FA. 2015. Logika Antropologi. Jakarta : Pradnya Media.

2006. Antropologi Kontemporer Suatu Pengantar Kritis Mengenai Paradigma. Jakarta : Prenada Media.

Spradley P., James. 2006. Metode Etnografy. Jakarta : Tiara Wacana.

Steward, Julian H. 1979. Theory of Culture Change. University of Illinois Press.

Suria, Sumantri. 2009. Filsafat Ilmu Sosial Pengantar Populer. Jakarta : Sinar Harapan.

Van, Bali J. 1987. Sejarah dan Pertumbuhan Teori Antropologi Budaya. Jilid 1. Jakarta : Gramedia. Jakarta : Gramedia.

1988. Sejarah dan Pertumbuhan Teori Antropologi Budaya. Jilid 2.

Zapral, Khan, 2015. Filsafat Ilmu Sosial Analisis Kontemporer. Jakarta : Rajawali Press. 